
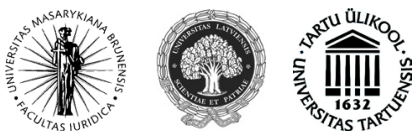

ISSN 1392-6195 (print) ISSN 2029-2058 (online) JURISPRUDENCIJA JURISPRUDENCE 2014, 21(2), p. 355-372.

\title{
AN INTERNATIONAL ANSWER TO CAPTURING CORPORATE CRIMINALITY
}

\author{
Mohammed Saleem Tariq \\ BPP University College, BPP Law School \\ 68-70 Red Lion Street, London, WC1R 4NY, United Kingdom \\ Tel.: 07769277627 \\ E-mail: Saleemtariq1987@gmail.com \\ Submitted on 10 of May, 2014; accepted on 24 May, 2014
}

doi:10.13165/JUR-14-21-2-02

\section{Introduction}

In the international sphere, there has been a unifying consensus against the recognition of a distinct corporate personality and, as it is expected, it has no such doctrine in place ${ }^{1}$. Some countries (e.g., Greece) have opted to impose administrative penalties emphasising the dichotomy between corporate entities and 'the corpus of criminal law' as developed to fit the psychology and human characteristics for human defendants ${ }^{2}$. In light of this, around the world there have been episodes of corporate accidents that have resulted in grave and unaccounted for injustice.

1 For example, Brazil does not run a doctrine of corporate criminal liability.

2 Robinson, A.A. Corporate Culture as a Basis for the Criminal Liability of Corporations. United Nations Special Representative of the Secretary-General on Human Rights and Business. February, 2008 [interactive]. [accessed on 30-03-2014]. <http://198.170.85.29/Allens-ArthurRobinson-Corporate-Culture-paper-for-Ruggie-Feb-2008.pdf $>$.

Jurisprudencija/Jurisprudence

(C) Mykolo Romerio universitetas, 2014

(C) Mykolas Romeris University, 2014
ISSN 1392-6195 (print), ISSN 2029-2058 (online) http://www.mruni.eu/lt/mokslo_darbai/jurisprudencija/ http://www.mruni.eu/en/mokslo_darbai/jurisprudencija/ 
In continental Europe and many other countries, however, the corporate veil has been lifted ${ }^{3}$. Alarmingly, on this side of legislative research and development, nations have now retired with several exhausted models for capturing corporate criminal liability. A revolutionary jurisprudence that shelves awkwardly in the most recent ones archives as a deterrent instead of what it should be: an active punitive measure against a corporate criminal.

The reality of modern day decision making in multinational corporations equally requires a fault based model which focusses primarily on their corporate culture. This paper evaluates the success of the corporate culture model advanced by the Australian Criminal Code Act 1995, in a comparative analysis with other international models of corporate fault. The importance and viability of the corporate culture model is emphasised for its sound applicability in honouring the idea that those multinational corporations bear responsibility towards global social justice.

\section{Background approaches to Corporate Criminal Liability}

In comparison to the background of criminal law, it became a forefront notion to depart from principles of vicarious liability in order to attach criminal liability to a company at the time it commissioned the offence. It is noted, however, that South Africa avoided difficult corporate prosecutions by transferring vicarious principles into the corporate field. Circumventing the approach of Tesco, the route of 'vicarious criminal liability' has unearthed a grievous attack to the fabrics, which stitch up the universal criminal justice system. Critically, outside the sphere of corporate liability, vicarious principles would not derive culpability from another being. By the same virtue, the corporate defendant should not have the requisite culpability drawn from individuals within the organization.

The legitimacy of corporations is perceived by Canada, Denmark and the United Kingdom amongst others, to 'derive from the individual consents of national persons' ${ }^{3}$. In metaphorical terms, the company is perceived to have 'no soul to damn or body to kick ${ }^{25}$, and therefore, it cannot commission suspect activity in the absence of its human counterparts. In stark contrast, realists objectify the levied criticism towards corporate entitles. The legislators of Australia, for instance, have derived corporate culpability (by means of the corporate culture doctrine, see, for instance, the Criminal Code Act 1995, 12.3) from a corporate culture without the need to

3 Salomon v. Salomon and Co. Ltd. (1897) A.C 22.

4 Wells, C. Corporate Liability and Consumer Protection: Tesco v Nattrass Revisited. Mod. L. Rev. 1994, 57.

5 Welks, K. Corporate Criminal Culpability: An Idea Whose Time Keeps Coming. Colum. J. Envtl. L. 1991, 16: 1293. 
reduce that culpability 'to the acts and omissions of individuals' ${ }^{\text {' }}$. Wells provides examples how with the legal answer the following equation is correct: $2+2=5^{7}$.

\section{The identification principle}

In order to restore social justice to its norm, the House of Lords used literary devices to impute criminal liability onto a corporate body and, in doing so, it is submitted, found the right defendant to prosecute against heinous crimes.

The civil origins ${ }^{8}$ of the identification principle made a radical shift into the criminal sphere 9 . The mechanisms became more apparent in the case of H.L. Bolton (engineering) Co Ltd v T. J Graham Sons Ltd, but did not establish a running precedent until Tesco Supermarkets $v$ Nattrass.

The Lords theorised that the 'brains', or the 'directing mind and will' of the company, could be accepted in law as the 'state of mind of the company and [will] be treated by law as such ${ }^{10}$, in order to attach a requisite degree of fault to a corporate body. Lifting the veil on who would constitute the directing mind and will, Lord Reid expressed it could be 'the board of directors, the managing director and perhaps other superior officers of the company who carry out the functions of management and speak and act for the company'll. Conversely, 'some people in the company are mere servants and agents who are nothing more than the hands to do the work'12. Offering perspective on the matter, Nwafor declares that 'the attribution of the fault of the employee to the company has the legal implication of infusing the fault of the employee in the company and so the law see's one and not two offenders'13. Identification simpliciter does, on the other hand, support the view that these corporations are 'better able to avoid the commission of offences then individuals'14, as exampled by Bhopal.

6 Wells, C. Corporations and Criminal Responsibility. Oxford: Clarendon Press, 1993.

7 Ibid.

$8 \quad$ Lennard's Carrying Co Ltd v Asiatic Petroleum Co Ltd [1915] AC 70.5.

$9 \quad R v$ ICR Haulage Ltd [1944] KB 551.

10 H.L. Bolton (engineering) Co Ltd v T. J Graham Sons Ltd [1957] 1 QB 159.

11 Tesco Supermarkets $v$ Nattrass [1972] AC 153 (HL).

12 H.L. Bolton (engineering) Co Ltd v T. J Graham Sons Ltd [1957] 1 QB 159.

13 Nwafor, A.O. Corporate Criminal Responsibility: A Comparative Analysis. J.A.L. 2013 [interactive]. [accessed on 30-03-2014]. <http://login.westlaw.co.uk/maf/wluk/app/search/ run?ao=o.I1714DB1E1DD211B29336B5006208D133\&ndd=2\&sttype=stdtemplate\&srguid =\& context=18\&crumb-action=append\&crumb-label=Search + Results\&sortid=secondary-orderi ng\&ntocview=I1714DB1E1DD211B29336B5006208D133\&frt=\&subkeyword $=\&$ atitle $=\&$ ana me $=$ nwafor\&def-term $=\&$ buttonSearch $=$ Search $>$.

14 Hill, J. Corporate Criminal Liability in Australia: An Evolving Corporate Governance Technique? J.B.L. 2003 [interactive]. [accessed on 30-03-2014]. <http://papers.ssrn.com/sol3/ papers.cfm?abstract_id $=429220>$. 
Amongst British Commonwealth countries, substantive theoretical and practical concerns soon welcomed a series of articulated academic criticism against the continuation of the Tesco principle within their respective jurisdiction.

At the expense of accountability, the identification principle inadvertently allowed for the directing mind and will to become insulated from legal ramifications by training and sub delegation of senior like activities amongst groups of employees. Lord Reid's restrictive interpretation of the principle in Tesco takes a depot engineer ${ }^{15}$, a weighbridge operator ${ }^{16}$ and a European sales manager ${ }^{17}$ outside the scope of the directing mind and will principle for the legal interests of maintaining predictability. This leaves each jurisdiction certain of one crucial motivating factor for reform 'provided no senior officer actively commits an offence, the corporation will not be liable ${ }^{18}$. As Wells concludes, 'it can result in no-one being liable' ${ }^{19}$. Wilkinson consciously entertains its effectiveness on occasion, where the management structure is much more concentrated and 'a controlling officer of senior standing would be much less difficult to pinpoint ${ }^{20}$, though the argument in favour of a corporate criminal liability regime becomes self-defeated.

As a direct consequence, the position pre Tesco remains the same post Tesco. It is inconceivable to justify a regime that targets only the flatter hierarchy of the petite company, when its activities have less impact to cause the level of corporate massacres that are the result of the activities exercised by larger enterprises. It is unquestioned how this doctrine 'improperly reflects the limits of moral responsibility ${ }^{21}$ for it to be a workable model of corporate fault.

Subsequent common law cases arrived to challenge the viability of the identification principle. The irony behind this principle was recognised in Tesco Stores Ltd $v$ Brent London Borough Council and $R v$ British Steel plc, namely that 'it works least in cases where it's needed the most ${ }^{22}$. Even less clear is the status of liability when decision making by senior management is diffused geographically. It is thought, perhaps, that this driving force led the Criminal Law Convention on Corruption 1999 and the Second Protocol of the EU Convention on the Protection of the European Communities' Financial Interests to introduce an 'expanded' version of 'identification simpliciter' as a means of casting a more realistic net of liability

15 Magna Plant Ltd v Mitchell [1996] Crim LR 396.

16 Henshall v Harvey [1965] 2 Q.B 233.

17 Redfern v Dunlop Rubber Australia Ltd (1964) 110 CLR 194.

18 Hill, J., op. cit. 14.

19 Wells, C., op. cit. 4, p. 2.

20 Fisse, B., and Braithwaite, J. Corporations, Crime \& Accountability. Cambridge University Press, 1993.

21 Wells, C., op. cit. 4, p. 2.

22 Gobert, J. Corporate Criminality: Four Models of Fault. Legal Studies. 1994, 14. 
over corporations. A conceptual shift in liability, however, circulates the same shortcomings of the original identification doctrine.

\section{Canada}

The above-mentioned concerns overflow into the Canadian regime. With expanding the identification principle, the pool of class widened for fault elements other than negligence ${ }^{23}$. Section 22.2 of the Canadian Criminal Code shapes the model of 'Tesco plus'. 'In respect of an offence that requires the prosecution to prove fault - other than negligence - an organisation is a party to the offence if, with the intent at least in part to benefit the organization, one of its senior officers:

(a) acting within the scope of their authority, is a party to the offence;

(b) having the mental state required to be a party to the offence and acting within the scope of their authority, directs the work of other representatives of the organization so that they do the act or make the omission specified in the offence; or

(c) knowing that a representative of the organization is or is about to be a party to the offence, does not take all reasonable measures to stop them from being a party to the offence'.

The significant implication of this model is that it breaks free of the need to search for the directing mind and will in place of a 'senior officer'. It is questionable why the directing mind and will could not also have alluded to a wider pool by way of interpretation, since senior officer is arguable the same difference in the search for an individual who could represent the company's culpable psyche. The threshold has, however, been lowered to cover the activities of mid-level managers 'who, while not responsible for setting corporate policy, are empowered to implement it' ${ }^{24}$.

Ironically, judicial developments that had ripened the doctrine of corporate criminal liability could not, after its running operations, prosecute either a company or three of its employees in the face of 26 left dead miners ${ }^{25}$. The subsequent case law demonstrates how 'Tesco plus' works in the field of corporate criminal law ${ }^{26}$. Going beyond the orthodox Tesco realm and into an expanded identification approach was a step short of a revolutionary workable concept $\mathrm{t}^{27}$.

The drawbacks of 'Tesco light' go further than searching through the organization for the directing mind and will. Parent companies, geographically located companies, and corporate fault still fall outside of this model. Academics are of the view that

23 The Canadian Criminal Code, s 22.2.

24 Nwafor, A.O. op. cit. 13.

25 The Westray Mine incident of May 1992.

$26 \quad R v$ Les Pétroles Global Inc, No 450-73-000633-085 (002), 9 August 2013 (SC).

27 See Bill c-284, where a corporate culture model was sought and drafted prior to being dismissed for the 'expanded identification' approach in Canada. 
'employees are not the accused; the corporation is, and the employee will always be too junior for [their] state of mind to be the corporations ${ }^{22}$. As a consequence, the law will find a corporate body guilty even where it cannot refuse to accept illicit benefits in comparison to the scenario where it knowingly accepts the intended benefit ${ }^{29}$.

\section{The United Kingdom}

The directing mind and will principle took on a new form in the United Kingdom for the offence of corporate manslaughter by virtue of the Corporate Manslaughter and Corporate Homicide Act 2007 (CMCHA). Supplemented by further requirements, it theorises that 'an organisation shall be found liable for the offence of corporate manslaughter provided that the prosecution can demonstrate it is due to:

The way its activities are managed or organised by its senior management which caused:

1. a person's death; and

2. amounts to a gross breach of a relevant duty of care owed by the organisation to the deceased'.

A desirable feature of this Act is that it would hold the parent company responsible for its subsidiaries, even when geographically widespread. In discussion of the Acts scope, Bastable notes that 'it appears inconsequential whether the breach of the relevant duty or the management failure occurred outside the territory ${ }^{30}$. Should death occur outside UK parameters, this provision could be rendered near obsolete. By virtue of the CMCHA, the occurrence of death, unless within the UK, will not trigger the protection of the $\mathrm{Act}^{31}$.

It appears onerous for the prosecutor to further evidence that death must also have been 'caused' by the activities managed or organised by senior management. Once causation is established, it must also be shown that management failure constituted a gross breach of a relevant duty of care. It is envisaged that a number of deaths could slip through the CMCHA's protection, where the accused's conduct met the standard expected of a reasonable man.

28 See: Card, R. Card, Cross and Jones. Criminal Law. 13th edition, London: Butterworths, 1995. See also: Cartwright, P. Consumer Protection and the Criminal Laws: Law, Theory, and Policy in the UK. Cambridge University Press, 2001.

29 Nwafor, A.O., op. cit. 13.

30 Bastable, G. Making a Killing. Euro. Law. 2008, 15.

31 Tariq, M.S. A 2013 Look at the Corporate Killer. Comp. Law. 2014 [interactive]. [accessed on 30-03-2014]. <http://login.westlaw.co.uk/maf/wluk/app/document?\&suppsrguid=ia744d0640 0000144bcaffab999df3af8\&docguid=IFB6AB1105C9611E39CCD8870F45B3314\&hitguid=I88 C0A7505D5411E38178C897FB92C2C4\&rank=1\&spos=1\&epos $=1 \& \mathrm{td}=135 \& \mathrm{crumb}$-action=a ppend \& context=6\&resolvein $=$ true $>$. 
It would be difficult to argue, as Gobert notes, that 'these managers were not accessories to that offence ${ }^{32}$. By the very depth of evidence required against the activities organised by senior management, there may be scope for the parliament to rethink negligence for the purposes of holding individuals liable by alternative means and distinguish this from a doctrine of corporate criminal liability.

Forgoing the complex nature that these provisions are entangled in, the requirement of senior management unsurprisingly echoes the difficulties associated with identifying the directing mind and will. Not only is this approach objective, but it is more elusive when weighed against its predecessor by the mere fact of a finding that the senior tier of management played a significant enough role in the management of corporate activities. Unearthing the universal dilemma for corporate criminal liability doctrines, Gobert highlights that we continue to allow its focus to be deflected from systematic fault to individual fault ${ }^{33}$.

\section{South Africa}

The concept behind South Africa's regime of corporate criminal liability is inspired by the tortious principles of vicarious liability, a less then innovative effort to reform the fallacies of the identification doctrine.

Perhaps the most profound assault of 'vicarious criminal liability' is the requirement for an identified person in the offence, other than the corporation, to be named on indictment. Concurrent to this, liability is placed on a juristic person. There is an unjustifiable awkwardness that resonates with placing liability on a corporate body that is recognised as committing the offence, but by the same virtue a representative is identified within the indictment for that offence. In consequence, the very basis for establishing vicarious corporate criminal liability is put on trial.

The codified position waters this argument south. It is explained that a person appears as a representative simply fulfilling the procedural element of a court war ${ }^{34}$. Yet the representative in question cannot be any mere servant ${ }^{35}$ or an incompetent senior for that matter ${ }^{36}$. Kriegler notes that in practice this seldom if ever happens and there are no known judgments to this effect since the coming into operation of Act 51 of $1977^{\prime 37}$.

32 Gobert, J. The Corporate Manslaughter and Corporate Homicide Act 2007 - Thirteen Years in the Making but Was It Wait the Worth? 2008, 71(3): 413.

33 Ibid.

34 The Criminal Procedure Act 1997, s 332(2).

$35 \quad R v$ Hammersma 1941 OPD 39.

36 Herold, N.O. v Johannesburg City Council 19472 SA 1257 (A) 1257, 1266-1267.

37 Kriegler, J., and Kruger, A. Hiemstra Suid-Afrikaanse Strafproses. 6th edition. London: Butterworths, 2002. 
Section 332 (1) of the Criminal Procedure Act 1977 provides the following:

'For the purpose of imposing upon a corporate body criminal liability for any offence, whether under any law or at common law -

(a) any act performed, with or without a particular intent, by or on instructions or with permission, express or implied, given by a director or servant of that corporate body; and

(b) the omission, with or without a particular intent, of any act which ought to have been but was not performed by or on instructions given by a director or servant of that corporate body,

In the exercise of his powers or in the performance of his duties as such director or servant or in furthering or endeavouring to further the interests of that corporate body, shall be deemed to have been performed (and with the same intent, if any) by the corporate body or, as the case may be, to have been an omission (and with the same intent, if any) on the part of that corporate body.'

Although it is a similar take on the vicarious principles adopted in the US in that it disregards the rank/status of an employee to impute culpability onto the respective corporation, the South African model is largely ambiguous. As explicitly stated, the acts and omissions of the director or servant will be sufficient to transfer culpability to the corporate. As wide as this approach is, it glosses over the level of involvement of an individual in that it may be too insignificant to satisfy the element which constitutes high mens rea offences. The model does not capture grouped criminal activity in the form of attribution rules, alternatively, so it may nevertheless fail in some cases.

Nwafor suggests for a more suitable provision to be formulated, one which would require the company to have benefited from a servant or directors conduct ${ }^{38}$. It is submitted that good practice in itself should ensure the company financially benefits through legal mediums. Yet under section 332, the employee who furthers this interest in culpable ways would have his culpability imputed to the corporation even when those interests are materially different. Conversely, it may be argued that the vicarious criminal approach to imputing liability onto a corporation is a legally accepted way of imposing strict liability through the back door and by doing so it destroys 'the fault element that makes an act a crime ${ }^{339}$. In truth, the blurred approach taken is a silent cry representing international inconsistences with corporate criminality and the difficulty involved with derivative models of corporate fault.

\section{The United States}

The United States leading doctrine of corporate criminal liability departs from the ratio, which declares that a principal should not be answerable 'for the acts of 
the deputy as he is in civil cases ${ }^{40}$ with Respondeat Superior. Like the approach taken in South Africa, this model dismantles the boundaries between civil liability and criminal liability, unjustly so. The doctrine enters by virtue of Federal Law and will find a corporation liable, where it can be established that the individual's actions, whether an officer, employee or agent, were within the scope of their duties (when pursuing illegal and criminal conduct) and that the individual's actions were intended, at least in part, to benefit the corporation. The inherently difficult task of drawing a distinction between an employee's interest and the interest of the company is precluded by the reason of the interest needing to be only partial ${ }^{41}$.

The provisions are slightly misleading, but in unambiguous terms the individual employee would need to have 'committed the offence in the course of pursing objectives or undertaking tasks which are authorised or required in their position' ${ }^{42}$. This is so even where express instructions have been given to avoid the conduct constituting the offence ${ }^{43}$. In the event that an individual cannot be identified due to evidential uncertainty, the company, inevitably, roams free from criminal liability. Conversely, there is a sustainable argument, which emphasises its 'over accountable' nature $^{44}$ (the discussion of the Criminal Procedure Act 1997 for capturing corporate fault in South Africa is relevant here).

\section{Australia}

In an experimental corporate liability regime, it has been widely accepted for the requisite mens rea of a directing mind and will to represent the company's thought processes yet intentionality through the corporate's very own ethos has been denied. It would make more sense to have found corporate criminal culpability that was not shared, an argument followed into the codified rules of the Criminal Code Act 1995. By the very virtue of this Act, the federal state of Australia devised a regime that would combat fragmented management structures through its corporate culture mechanism. Against the mythological individualist ${ }^{45}$ conception, a breakthrough allowed for a workable principle.

Critically, international jurisprudence has since championed a particular thought process. For instance, if A tackles B, and A was carrying a football at the material time, A has made the resolution that he is playing football. Sullivan continues that where a collective intention to play is instituted, individual intents 'flow downwards

40 Huggins (1730) 2 LD Raym 1574.

41 See the case of United States v Sun-Diamond Growers of California 526 U.S. 398 (1999).

42 Robinson, A.A., op. cit. 2.

43 Ibid.

44 Ibid.

45 Fisse, B., and Braithwaite, J., op. cit. 20. 
from the collective intent to play ${ }^{346}$. Through academic scrutiny, Fisse and Braitwaite opine that group thinking forms something different to individual expectations. In their example, if the Whitehouse were to proceed with international intervention, it is not being said that all individuals of the United States have become unified in their thinking. The true reflection would be that these opposing individuals are embedded in the Whitehouse's decision ${ }^{47}$. The decision of the Whitehouse is, therefore, based on its own intentionality and in tune with this reasoning Australia brought forward the 'most sophisticated model of corporate criminal liability in the world'48.

The corporate culture doctrine works best at the stage of liability. In contrast to international conventions ${ }^{49}$, Part 2.5 of the Criminal Penal Code identifies the corporate body as the sole perpetrator of a mens rea offence by casting focus on its culture $^{50}$. The corporate's culture is said to be the 'attitude, policy, rule, course of conduct or practice existing within the body corporate generally or in the part of the body corporate where the offence occurred ${ }^{351}$. Its far reaching scope attaches liability in two innovative ways ${ }^{52}$. It appears that liability would attach if it can be proven by the prosecution that the corporate's culture directed, encouraged, tolerated or led to non-compliance with the relevant provision ${ }^{53}$, or where the body corporate failed to create and maintain a corporate culture that required compliance with the relevant provision ${ }^{54}$. In terms of mens rea offences, the approach is designed to capture intention, knowledge, recklessness and negligence ${ }^{55}$ and provided the culture 'expressly, tacitly, or impliedly authorised or permitted the commission of the offence ${ }^{56}$, the prosecution has made its case.

This approach is welcomed for its ability to 'catch managerial techniques against which Tesco was powerless - such as when employees, under implied threat of dismissal, are given production deadlines which cannot be met without, for

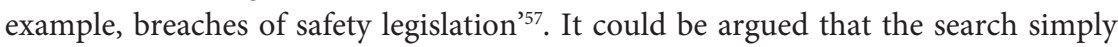
shifts from locating a directing mind and will to locating fault from an immaculate

Sullivan, G.R. Expressing Corporate Guilt. O.J.L.S. 1995.

Fisse, B., and Braithwaite, J., op. cit. 20.

Clough, J., and Mulhern, C. The Prosecution of Corporations. Oxford University Press, 2002.

Rome Statute, Article 25.

Criminal Code Act 1995, 12.1(1) and (2).

Criminal Code Act 1995, 12.3(6).

Criminal Code Act 1995, 12.3(2)(c) and (d).

Criminal Code Act 1995, 12.3 (2)(c).

Criminal Code Act 1995, 12.3 (2)(d).

Criminal Code Act 1995, 12.3 (2).

Criminal Code Act 1995, 12.3 (1).

See the Explanatory Memorandum to the Criminal Code Bill, 1994. 
policy. Cavanagh contends that the search for the latter would be less burdensome ${ }^{58}$. Even so, this does not prevent an enterprise from continuing their conduct with unwritten rules and showcase policies ${ }^{59}$. The erroneous task of implementing an inadequate programme, to run this daily at potentially hazardous costs and suffer setbacks at an unsustainable level eases the tension for Wissemen regarding showcase policies ${ }^{60}$. Should a company inevitably decide to erect a criminal policy behind its immaculate one, then there is little doubt of criminal penalties circulating around that very corporate entity. It is unlikely, however, for the company to have supported a criminally unwritten rule 'at or before the time of the commission of the actus reus of an offence ${ }^{61}$. Nevertheless, one must be cautious that unwritten rules in a trial and before a panel of jurors could be explained away.

Further, these principles assume that authorisation or permission will be granted either explicitly or implicitly. It does not take into account that the above form of authorisation may not have been given at all. A third option is unavailable. Hill has criticised this on the grounds that reactive failure during these circumstances is an important indicator of fault at the organizational level ${ }^{62}$ and yet what 'may be a highly relevant indicator of corporate culture does not appear in the express factors set out in $s 12.3(4)^{363}$. One school of thought is that reactive fault may be 'too much of a departure from fundamental principles of criminal laws...to be regarded as a tenable basis for corporate liability ${ }^{364}$ to form part of the corporate culture model.

The Act still makes room to find liability through other means ${ }^{65}$ and attaches the necessary culpability to the company. Using the framework of criminal law, the criminal code bill has respected core criminal principles to fit a new kind of defendant without roaming into strict and vicarious grounds for attaching liability. It promotes the credibility of the corporate criminal liability regime and nurtures its growth whilst striving for universal acceptance and incorporation. The tired arguments

58 Cavanagh, N. Corporate Criminal Liability: An Assessment of the Models of Fault. JCL. 1 Oct 2011 [interactive]. [accessed on 30-03-2014]. <http://login.westlaw.co.uk/maf/wluk/ app/document?\&srguid=ia744d05e00000144bcb605d71b1e530e\&docguid=I0DB4B2F283D E11E18B169914E7D68498\&hitguid=I0DB4B2F283DE11E18B169914E7D68498\&rank=1\&s pos $=1 \&$ epos $=1 \& \mathrm{td}=5 \&$ crumb-action $=$ append $\&$ context $=12 \&$ resolvein $=$ true $>$.

59 Fisse, B. Recent Developments in Corporate Criminal Law and Corporate Liability to Monetary Penalties. UNSWLJ. 1990.

60 Weissmann, A. A New Approach to Corporate Criminal Liability. Am. Crim. L. Rev. 2007, 1319.

61 Cavanagh, N., op. cit. 58.

62 Hill, J., op. cit. 14.

63 Ibid.

64 Wilkinson, M. Corporate Criminal Liability - The Move Towards Recognising Genuine Corporate Fault. Canta LR. 2003, 9.

See the Criminal Code Act 1995, 12.3 (2)(a) and (b). 
against adopting this model have watered down and have now formed part of the ideas that urge reform in outside jurisdictions ${ }^{66}$.

\section{Corporate culture application}

The corporate culture phenomenon is the ultimate practical model for capturing a culpable corporate enterprise when its policy commissions a mens rea offence. But how would this model operate concurrently within the general areas of corporate criminal liability?

Under the Trade Practices Act 1974, in determining all relevant matters, the court must give regard to the corporate culture and decide whether it directed, encouraged, tolerated or led to non-compliance of the offence under the $1974 \mathrm{Act}^{67}$. To this end, an organisation involved in price fixing regurgitated $\$ 26$ million in penalties after a criminal prosecution ${ }^{68}$. In other cases, the court has ordered a company to pay an aggregated penalty in fines of $\$ 6.5$ million under the final court settlement ${ }^{69}$.

Due to its far reaching nature, there is a strong line of argument in support of finding a corporate body criminally liable where its culture promotes, authorises, permits or tolerates private sector briberies for the offence of bribing a foreign public official.

The revised Guide to Business Conduct, released by BHP Billiton Ltd in 2000, details their anti-bribery compliance systems in tune with the notion that its culture should expressly prohibit activities that would otherwise render it criminally liable for bribery offences, stating that:

'In international business, in particular, employees may sometimes come under pressure to make payments or payments in kind to induce others improperly to grant permits or services to which BHP would not generally be entitled. Never make or agree to make such payments.

Under no circumstances will BHP approve any irregular payment or payment in kind to win business or to influence a business decision in the company's favour. Bribes, 'kick-backs', secret commissions and similar payments are strictly prohibited. Moreover, they may expose BHP and relevant employees to criminal prosecution and serious penalties...'

It is envisaged that for many offences, the corporate culture would be an overriding factor. Liability would ultimately attach if it can be proven by the prosecution that

66 See the report of a public inquiry into the Westray Mine Incident of May 1992.

67 ACCC $v$ Safeway Stores Pty Ltd (1997) A.T.P.R.; ACCC $v$ George Weston Foods Ltd (2000) A.T.P.R.; ACCC $v$ Simsmetal Ltd (2000) A.T.P.R. 41-764.

68 CCC v Roche Vitamins Australia Pty Ltd (2001) A.T.P.R. 41-809.

69 Trade Practices Commission v TNT Australia Pty Ltd (1995) A.T.P.R. See also: ACCC v Pioneer Concrete (Qld) Pty Ltd (1996) A.T.P.R. 
the corporate's culture directed, encouraged, tolerated or led to non-compliance with the relevant provision ${ }^{70}$ or where the body corporate failed to create and maintain a corporate culture that required compliance with the relevant provision ${ }^{71}$. The model rains supreme over the derivate regimes in force in several jurisdictions and has stood the test of time to evidence its practical nature. The answer to finding an effective corporate criminal liability doctrine has been a 'diamond' in the contours of section 2.5 of the Australian Penal Code.

\section{Further thoughts}

The purpose of attaching criminal liability is to further the overall aims and objectives of criminal laws and in the corporate sphere, as a means of influencing corporate behaviour. The sentencing factors used by the United States ${ }^{72}$ are arguably the most advanced in the world. Such factors include corporate culture considerations in the aspect of fines and corporate probation. The guideline provides for the implementation of compliance and ethics programs intended to 'foster [the] reform of the corporate culture of defendants ${ }^{73}$. Mitigating factors are also available for having in place an effective compliance and ethics program. It is submitted that the incorporation of these sentencing guidelines in a workable corporate fault model would introduce to the world a new kind of culpable entity.

One further critique of the corporate culture model is aimed towards the due diligence provision. A defence against the imposition of criminal liability for high mens rea offences sits uncomfortably in the realms of criminal jurisprudence. The removal of this defence from the corporate culture model would not, by consequence, create a strict liability approach. There would still be room for a corporate body to show that its culture did not explicitly or implicitly authorise the commission of an offence to attract criminal liability.

\section{Conclusion}

This paper has examined worldwide troubles with engineering an effective doctrine of corporate criminal liability. Judicial pronouncement of the identification doctrine in Tesco opened the gateway for attributing criminal liability to a corporate body through its directing mind and will. In theory, the model was long desired, given the rise of crime unaccounted for. Practically, however, the model fails to find

\footnotetext{
70 Criminal Code Act 1995, 12.3 (2)(c).

71 Criminal Code Act 1995, 12.3 (2)(d).

72 See the Federal Sentencing Guidelines Manual 2006 s 8B2.1

73 Robinson, A.A., op. cit. 2.
} 
a company criminally responsible. With shared concern cross international minds, this paper has documented the crux of the universal dilemma.

In overall summary, corporate entities must, by their very operational nature, delegate duties down its hierarchy, reaching base level employees. In doing so, hundreds and even thousands will play an insignificant part in effecting a criminal offence. The directing mind and will, otherwise seen as the elite bench of senior officers, will have no hand in their activities. The prosecutor cannot, for this very reason, demonstrate corporate culpability in a court of law. The requisite culpability is virtually absent from the very party that must show intention, recklessness and/or negligence. This leaves the current regimes rigid and unsuccessful as a mechanism for censuring criminal operations within corporate entities.

In other jurisdictions, liability is unchecked. Here, any employee within the organisation, who purses criminal activity to benefit himself, will, by consequence, hold the company liable for that criminal offence. One could defend a more extreme model of corporate fault by resurrecting controversial ideas such that distinguish a human defendant from a defendant who can or cannot do something without its human agents. It is submitted that this justification does not negate the bigger crime of prosecuting a corporate defendant who lacks the appropriate mens rea. Ultimately, it ventures as a mechanism, as Moohr expresses, one which is inconsistent with the basic requirements of criminal law: the accused must engage in the conduct with appropriate culpability and these elements must occur in time ${ }^{374}$.

In the end, a 'criminal' has evolved into the corporate sphere with a new kind of culpable entity, as appreciated by the Australian Criminal Code Act 1995. A culture that represents the mind of the company and evidences whether it directed, encouraged, tolerated or led to non-compliance with the relevant provision ${ }^{75}$ or where it failed to create and maintain a corporate culture that required compliance with the relevant provision ${ }^{76}$.

The theoretical simplicity of imputing the requisite mens rea onto a corporation through its top echelon quickly trended the primary mechanisms for subsequent fault based models in several jurisdictions. In doing so, this inadvertently narrowed the scope to work outside of a nominalist approach and develop an inherently practical model for capturing true corporate fault. A universal reform to the principles of the current corporate criminal doctrine is therefore required.

Straying from the model alternatively leaves legal hands with the 'difficult choice of [either] setting an arbitrary limit as to who may act as the company or have no limit at all, and either give up all attempts at corporate criminal responsibility or

74 Moohr, G.S. Of Bad Apples and Bad Trees: Considering Fault-base Liability for the Complicit Corporation. Am. Crim. L. Rev. 2007, 44: 1343.

75 Criminal Code Act 1995, 12.3 (2)(c).

76 Criminal Code Act 1995, 12.3 (2)(d). 
suffer the injustices of vicarious liability ${ }^{77}$. The surety is this: we cannot retract a doctrine of corporate criminal liability in pursuit of universally accepted objectives of deterrence, retribution and justice and we cannot remain with an impractical model of corporate fault for the present. The answer is a move towards a realist based system which recognises criminality against the psychology of a corporate defendant through its very own culture. It is submitted that tinkering of the current models would only be prolonging the inevitable act of accepting and incorporating a holistic theory of corporate criminality.

\section{References}

ACCC $v$ George Weston Foods Ltd (2000) A.T.P.R.

ACCC $v$ Pioneer Concrete (Qld) Pty Ltd (1996) A.T.P.R.

Bastable, G. Making a Killing. Euro. Law. 2008, 15.

Card, R. Card, Cross and Jones. Criminal Law. 13th edition. London: Butterworths, 1995.

Cartwright, P. Consumer Protection and the Criminal Laws: Law, Theory, and Policy in the UK. Cambridge University Press, 2001.

Cavanagh, N. Corporate Criminal Liability: An Assessment of the Models of Fault. JCL. 1 Oct 2011 [interactive]. [accessed on 30-03-2014]. <http:// login.westlaw.co.uk/maf/wluk/app/ document? \&srguid=ia744d05e00000 144bcb605d71b1e530e\&docguid=I0 DB4B2F283DE11E18B169914E7D6 8498\&hitguid=I0DB4B2F283DE11E 18B169914E7D68498\&rank=1\&spo$\mathrm{s}=1 \&$ epos $=1 \& \mathrm{td}=5 \& \mathrm{crumb}$-action $=\mathrm{a}$ ppend \&context $=12 \&$ resolvein $=$ true $>$. CCC $v$ Roche Vitamins Australia Pty Ltd (2001) A.T.P.R. 41-809.
Clough, J., and Mulhern, C. The Prosecution of Corporations. Oxford University Press, 2002.

Fisse, B., and Braithwaite, J. Corporations, Crime \& Accountability. Cambridge University Press, 1993.

Fisse, B. Recent Developments in Corporate Criminal Law and Corporate Liability to Monetary Penalties. UNSWLJ. 1990.

Gobert, J. Corporate Criminality: Four Models of Fault. Legal Studies. 1994, 14.

Gobert, J. The Corporate Manslaughter and Corporate Homicide Act 2007 Thirteen Years in the Making but Was It Worth the Wait? 2008, 71(3).

Henshall v Harvey [1965] 2 Q.B 233.

Herold, N.O. v Johannesburg City Council 19472 SA 1257 (A) 1257, 1266-1267.

Hill, J. Corporate Criminal Liability in Australia: An Evolving Corporate Governance Technique? J.B.L. 2003 [interactive]. [accessed on 30-032014]. <http://papers.ssrn.com/sol3/ papers.cfm?abstract_id $=429220>$. 
H.L. Bolton (engineering) Co Ltd v T. J Graham Sons Ltd [1957] 1 QB 159.

Huggins (1730) 2 LD Raym 1574.

Kriegler, J., and Kruger, A. Hiemstra Suid-Afrikaanse Strafproses. 6th edition. London: Butterworths, 2002.

Lennard's Carrying Co Ltd $v$ Asiatic Petroleum Co Ltd [1915] AC 70.5.

Magna Plant Ltd v Mitchell [1996] Crim LR 396.

Moohr, G.S. Of Bad Apples and Bad Trees: Considering Fault-base Liability for the Complicit Corporation. Am. Crim. L. Rev. 2007, 44: 1343.

Nwafor, A.O. Corporate Criminal Responsibility: A Comparative Analysis. J.A.L. 2013 [interactive]. [accessed on 30-03-2014]. <http://login. westlaw.co.uk/maf/wluk/app/search/ run?ao=o.I1714DB1E1DD 211 B293 36B5006208D133\&ndd=2\&sttype $=s$ tdtemplate \&srguid $=\&$ context $=18 \& \mathrm{c}$ rumb-action $=$ append $\&$ crumb-label $=$ Search + Results\&sortid=secondaryordering\&ntocview $=\mathrm{I} 1714 \mathrm{DB} 1 \mathrm{E} 1 \mathrm{DD}$ 211B29336B5006208D133\&frt=\&sub keyword $=\&$ atitle $=$ \&aname $=$ nwafor $\&$ def-term $=\&$ buttonSearch $=$ Search $>$.

$R v$ Hammersma 1941 OPD 39.

$R v$ ICR Haulage Ltd [1944] KB 551.

$R v$ Les Pétroles Global Inc, No 450-73000633-085 (002), 9 August 2013 (SC).

Redfern $v$ Dunlop Rubber Australia Ltd (1964) 110 CLR 194.

Robinson, A.A. Corporate Culture as a Basis for the Criminal Liability of Corporations. United Nations Special Representative of the Secretary-General on Human Rights and Business. February 2008 [interactive]. [accessed on 30-03-2014]. <http://198. 170.85.29/ Allens-Arthur-Robinson-CorporateCulture-paper-for-Ruggie-Feb-2008. pdf $>$.

Sullivan, G.R. Expressing Corporate Guilt. O.J.L.S. 1995.

Tariq, M.S. A 2013 Look at the Corporate Killer. Comp. Law. 2014 [interactive]. [accessed on 30-03-2014]. <http:// login.westlaw.co.uk/maf/wluk/app/do cument? \&suppsrguid=ia744d064000 00144bcaffab999df3af8\&docguid=IF B6AB1105C9611E39CCD8870F45B3 314\&hitguid $=$ I88C0A7505D5411E38 $178 \mathrm{C} 897 \mathrm{FB} 92 \mathrm{C} 2 \mathrm{C} 4 \& \mathrm{rank}=1 \&$ spos $=$ $1 \&$ epos $=1 \& \mathrm{td}=135 \&$ crumb-action $=\mathrm{a}$ ppend \& context $=6 \&$ resolvein $=$ true $>$.

Weissmann, A. A New Approach to Corporate Criminal Liability. Am. Crim. L. Rev. 2007, 1319.

Welks, K. Corporate Criminal Culpability: An Idea Whose Time Keeps Coming. Colum. J. Envtl. L. 1991, 16: 1293.

Wells, C. Corporate Liability and Consumer Protection: Tesco v Nattrass Revisited. Mod. L. Rev. 1994, 57.

Wells, C. Corporations and Criminal Responsibility. Oxford: Clarendon Press, 1993.

Wilkinson, M. Corporate Criminal Liability The Move Towards Recognising Genuine Corporate Fault. Canta LR. 2003, 9. 


\title{
TARPTAUTINIS ATSAKAS KOVOJANT SU KORPORATYVINIU NUSIKALSTAMUMU
}

\author{
Mohammed Saleem Tariq \\ BPP teisės mokykla, Jungtinė Karalystė
}

\begin{abstract}
Anotacija. Verslo globalizacijos aplinkoje vis svarbesnè darosi korporatyvines kaltès kategorija. Atsižvelgiant i tai, kad korupcija vis tvirčiau isitvirtina verslo kultūroje, labai svarbu kovoti su esamomis didejančio korporatyvinio nusikalstamumo tendencijomis. Straipsnyje analizuojamas Australijos Baudžiamojo kodekso $1995 \mathrm{~m}$. aktas, kuris laikytinas pirmuoju žingsniu korporatyvinès kultūros doktrinoje kovojant su struktūriškai sudetingais korporatyviniais nusikalstamo pobūdžio susitarimais.

Reikšminiai žodžiai: žmonių nusikaltimai, valdymas, tarptautiniai korporatyvinés kaltès modeliai, mensrea, Tesco $v$ Nattrass, identifikavimo principas, valios ir proto nukreipimas, korporatyvinè kultūra, Jungtine Karalystè, Kanada, Jungtinès Amerikos Valstijos, Pietu Afrika, Australija.
\end{abstract}

\section{AN INTERNATIONAL ANSWER TO CAPTURING CORPORATE CRIMINALITY}

\author{
Mohammed Saleem Tariq \\ BPP Law School, United Kingdom
}

Summary. In the era of increased corporate globalisation, the lingering principles of directing mind and will have plagued South Africa, the United Kingdom, New Zealand, Luxembourg and the United States, amongst other neighbouring territories from manufacturing a realist model of corporate fault. The incorporation of absolute corporate liability in international governance documents has repeatedly fallen short of the expectations in the aftermath of Bhopal, Saveso and P \& O European Ferries and other ecological disasters alike. It is of fundamental importance to combat transnational corporate activity from a world order perspective by establishing a legal regime which supports the philosophy that corruption becomes entrenched within the corporate culture, a culture that is indicative of corporate guilt.

This paper will travel through several jurisdictions, identifying models of corporate fault, to determine their practicality, viability and legitimacy in the regime of corporate criminal liability. The paramount issues anchoring each jurisdiction from evolution in the respective doctrine is the requirement to locate a high mens rea offence from a directing mind and will and impute this onto the corporate defendant. Due to delegation of managerial responsibilities, the supposed mens rea offence takes places 
at base level, a technique that has insulated multinational companies from criminal liability. In other jurisdictions, the paper reveals strained attempts to make a derivative fault based model work, which is unsuccessful. Disregarding the employees rank and status to some extent, a corporate body is seen to be held criminally liable where it has partially benefited as a result of its employees actions whether intended or not and whether initially prevented, preventable or not preventable.

This paper will continue to examine and evaluate the only available realist model of corporate fault in workable form, as codified into the Australian Criminal Code Act 1995. The 'corporate culture' doctrine remedies the fallacies of a derivative approach and is successful against strategies employed by a larger institution, making it a workable model for capturing corporate fault. The rules pertaining to the model will be closely critiqued and viewed in light of a series of cases before concluding that this approach is the first step in the courses of action required against the evolution of structurally complex corporate arrangements.

Keywords: corporate crime, governance, international models of corporate fault, mens rea, Tesco $v$ Nattrass, identification principle, directing mind and will, corporate culture, UK, Canada, US, South Africa, Australia.

Mohammed Saleem Tariq, LexisPLS korporatyvinis teisininkas, buvęs „Atkin’s Court Forms“, „LexisNexis“, „Butterworths Ltd“ vyriausiasis redaktorius, „Lincoln’s Inn“, BPTC, BPP universiteto koledžo Londone teisininkas. Moksliniu tyrimų kryptys: korporatyvinis valdymas, korporatyvinis nusikalstamumas, civilinio proceso taisyklès ir tarptautinès komercinès teisès principai.

Mohammed Saleem Tariq, Corporate Paralegal, LexisPSL, former Senior Editor of Atkin's Court Forms, LexisNexis, Butterworths Ltd; Barrister-at-Law of Lincoln's Inn, BPTC, BPP University College, Holborn, London. Research interests: corporate governance, corporate crime, civil procedural rules and international commercial law principles. 